A Matter of Rats 
AMITAVA KUMAR 


\section{A Matter of Rats}

A SHORT BIOGRAPHY OF PATNA

Duke University Press $\quad$ Durham 2014 
(C) 2014 Duke University Press

All rights reserved

Printed in the United States of America on acid-free paper $\infty$ Designed by Courtney Leigh Baker

Typeset in Whitman by Copperline Book Services, Inc.

Library of Congress Cataloging-in-Publication Data

Kumar, Amitava, 1963-

A matter of rats : a short biography of Patna / Amitava Kumar.

pages $\mathrm{cm}$

Includes bibliographical references and index.

ISBN 978-o-8223-5704-9 (cloth : alk. paper)

1. Patna City (India)-Description and travel.

2. Kumar, Amitava, 1963-

3. Patna City (India)-Biography.

I. Title.

DS486.P26K86 2014

915.4'123-dc23 2013041901 
FOR MY PARENTS and FOR RAHUL, who wanted a book about the Power Rangers instead 
